\title{
口蓋腫瘍の臨床的検討
}

中島 幹 夫・鈴 木 健 男・竹 内 亘
真境名 由 弘・北 村 幸 郷

\section{Tumors of the Hard and Soft Palates}

\section{Mikio Nakashima, Takeo Suzuki, Wataru Takeuchi, Yoshihiro Majikina and Yukisato Kitamura}

(Tottori University)

Cases of tumor originating in the hard and/or soft palates experienced in this department between 1950 and 1979 have been reviewed and subjected to case analysis. The cases totaled up to 41 , of which 23 were benign and 18 malignat. Pleomorphic adenoma showed the highest incidence.

\section{は じめに}

口蓋には組織学的, 臨床的に多様性をもつ小唾液腺腫瘍が好発するため，口蓋腫瘍の臨床像は良 性か悪性かの判断が困難な場合が少なくない。このためわれわれは過去35年間に経験した口蓋腫瘍 41 例に対して臨床像, 組織像および治療成績の関係を検討したので報告する.

\section{症例と集計結果}

対象とした症例は昭和25年 1 月から昭和59年 12月までに鳥取大学医学部耳鼻咽喉科で経験し た原発性口蓋腫瘍41症例である。また口蓋腫瘍 は軟口蓋と硬口蓋に原発したものとし，軟口蓋 はUICCの定義に従って集計を実施した. 41 症 例中良性腫瘍が23例, 覀性腫瘍が18例であった (表 1，2）.

1. 性別分布

良性腫瘍は男 6 例, 女17例で女に多かった。 一方悪性腫瘍は男 12 例, 女 6 例で男に多かった (表 3 ).

2 . 年令別分布

良性腫瘍は11才から77才までで，平均年令

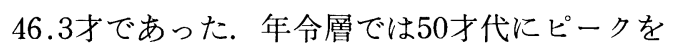

認めた，悪性腫瘍は37才から70才までで，平均 年令 59.2 才であった．年令層では60才代に著明 なピークを認めた。良性腫瘍に比較して悪性腫 瘍の年令層が高かった（表 4 ）.

3 . 発生部位別分布

発生部位を軟口蓋, 硬口蓋そして両口蓋にわ けて集計した．良性腫瘍は硬口蓋に16例（69.6 $\%)$, 悪性腫瘍は硬口蓋に11例（61.1\%）と硬口 蓋に好発していた，両口蓋にわたる症例が良性 腫瘍, 悪性腫瘍のいずれも 1 例存在していた (表 5 ).

\section{4. 初発症状}

初発症状としては口蓋腫瘤, 口蓋痛, 口腔の 不快感，頸部腫瘤の 4 つが認められた。良性腫 
表 1 良性口蓋腫瘍症例

\begin{tabular}{|c|c|c|c|c|c|c|c|c|}
\hline 㫌: & 例 & 年令 & 性別 & 部 位 & 組 織 型 & \multicolumn{3}{|c|}{ 治療 法 } \\
\hline 1. & & 65 & 女 & 硬口蓋 & 多形性腺腫 & 摘 & 出 & \\
\hline 2. & & 40 & 女 & 硬口蓋 & 多形性腺腫 & 摘 & 出 & 術 \\
\hline 3. & & 50 & 女 & 硬口蓋 & 血 管 腫 & 切 & 除 & 術 \\
\hline 4. & & 54 & 女 & 硬口蓋 & 外 骨 腫 & 切 & 除 & 術 \\
\hline 5. & & 21 & 女 & 軟口蓋 & 多形性腺腫 & 摘 & 出 & 術 \\
\hline 6. & & 43 & 男 & 硬口蓋 & 多形性腺腫 & 摘 & 出 & 術 \\
\hline 7. & & 21 & 女 & 硬口蓋 & 多形性腺腫 & 摘 & 出 & 術 \\
\hline 8. & & 46 & 女 & 軟口蓋 & 多形性腺腫 & 摘 & 出 & 術 \\
\hline 9. & & 65 & 男 & 硬口蓋 & 多形性腺腫 & 摘 & 出 & 術 \\
\hline 10. & & 61 & 女 & 硬口蓋 & 多形性腺腫 & 摘 & 出 & 術 \\
\hline 11. & & 50 & 女 & 硬口蓋 & 多形性腺腫 & 摘 & 出 & 術 \\
\hline 12. & & 40 & 女 & 硬口蓋 & 多形性腺腫 & 摘 & 出 & 術 \\
\hline 13. & & 32 & 女 & 硬口蓋 & 多形性腺腫 & 摘 & 出 & 術 \\
\hline 14. & & 22 & 女 & 軟口蓋 & 多形性腺腫 & 切 & 除 & 術 \\
\hline 15. & & 48 & 女 & 硬口蓋 & 外 骨 腫 & 切 & 除 & 術 \\
\hline 16. & & 77 & 男 & 硬口蓋 & 乳 頭 腫 & 切 & 除 & 術 \\
\hline 17. & & 38 & 女 & 軟口蓋 & 多形性腺腫 & 摘 & 出 & 術 \\
\hline 18. & & 58 & 女 & 硬口蓋 & 多形性腺腫 & 摘 & 出 & 術 \\
\hline 19. & & 64 & 男 & 硬口蓋 & 多形性腺腫 & 摘 & 出 & 術 \\
\hline 20. & & 55 & 男 & 軟・硬口蓋 & 多形性腺腫 & 摘 & 出 & 術 \\
\hline 21. & & 52 & 女 & 硬口蓋 & 外 骨 腫 & 末 & 治 & 療 \\
\hline 22. & & 53 & 男 & 硬口蓋 & 外 骨 腫 & 切 & 除 & 術 \\
\hline 23. & & 11 & 女 & 軟口蓋 & 乳＼cjkstart頭＼cjkstart腫 & 切 & 除 & 術 \\
\hline
\end{tabular}

表 2 悪性口蓋腫瘍症例

\begin{tabular}{|c|c|c|c|c|c|c|}
\hline 症 例 & 年令 & 性別 & 部 位 & 組 織 型 & 転 移 & 治 \\
\hline 1. & 70 & 男 & 軟口蓋 & 扁平上皮癌 & $(-)$ & ラジウム針 \\
\hline 2. & 69 & 女 & 硬口蓋 & 悪性リンパ腫 & 頸 部 & ${ }^{60} \mathrm{Co}$ \\
\hline 3. & 63 & 女 & 軟·硬口蓋 & 扁平上皮癌 & 頸 部 & ${ }^{60} \mathrm{Co}$, 広汎切除 \\
\hline 4. & 67 & 男 & 軟口蓋 & 腺様のら胞癌 & $(-)$ & Co, 広汎切除 \\
\hline 5. & 66 & 男 & 軟口蓋 & 扁平上皮癌 & 頸 部 & ${ }^{60} \mathrm{Co}$, 広汎切除 \\
\hline 6. & 65 & 男 & 軟口蓋 & 腺様のう胞癌 & $(-)$ & 単純摘出 \\
\hline 7. & 67 & 男 & 軟口蓋 & 扁平上皮癌 & $(-)$ & ${ }^{60} \mathrm{Co}$, 化学療法 \\
\hline 8. & 56 & 男 & 硬口蓋 & 腺様のう胞癌 & $H$ & ${ }^{60} \mathrm{Co}$, 広汎切除 \\
\hline 9. & 37 & 女 & 軟口蓋 & 腺様のら胞癌 & $(-)$ & 広汎切除 \\
\hline 10. & 60 & 女 & 硬口蓋 & 扁平上皮癌 & $(-)$ & ${ }^{60} \mathrm{Co}$, 化学療法 \\
\hline 11. & 40 & 男 & 硬口蓋 & 腺様のう胞癌 & 肺 & 3 者併用 \\
\hline 12. & 45 & 男 & 硬口蓋 & 乳頭状腺癌 & $(-)$ & 広汎切除, ${ }^{6)} \mathrm{Co}$ \\
\hline 13. & 65 & 男 & 硬口蓋 & 扁平上皮癌 & 頸 部 & 切除, 化学療法 \\
\hline 14. & 47 & 男 & 硬口蓋 & 扁平上皮癌 & $(-)$ & 広汎切除, 化学療法 \\
\hline 15. & 55 & 女 & 硬口蓋 & 扁平上皮癌 & $H$ & ${ }^{60} \mathrm{Co}$, 化学療法 \\
\hline 16. & 67 & 男 & 硬口蓋 & 扁平上皮癌 & $(-)$ & 3 者併用 \\
\hline 17. & 68 & 男 & 硬口蓋 & 扁平上皮癌 & 頸 部 & 3 者併用 \\
\hline 18. & 58 & 女 & 硬口蓋 & リンパ上皮腫 & 頸 部 & ${ }^{60} \mathrm{Co}$, 化学療法 \\
\hline
\end{tabular}


瘍, 悪性腫瘍とも口蓋腫㾴を初発することが多 かった（表 6 ）. 悪性腫瘍の頸部転移が初発症状 となった症例が 1 例あった.

5. 症状初発から治療までの期間

患者が症状を自覚してから治療をらけるまで の期間は様々である．悪性腫瘍では12例（70.0

表 3 口蓋腫瘍の性別分布

\begin{tabular}{c|r|r|r|r|r|r|r}
\hline \hline \multirow{2}{*}{ 性 別 } & \multicolumn{2}{|c|}{ 良性腫痬 } & \multicolumn{2}{|c|}{ 悪性腫瘍 } & \multicolumn{2}{|c|}{ 計 } \\
\cline { 2 - 7 } & 例数 & $\%$ & 例数 & $\%$ & 例数 & $\%$ \\
\hline 男 & 6 & 26.1 & 12 & 66.7 & 18 & 43.9 \\
女 & 17 & 73.9 & 6 & 33.3 & 23 & 56.1
\end{tabular}

表 4 口蓋腫瘍の年令別分布

\begin{tabular}{c|c|c|c}
\hline 年 令 & 良性腫瘍 & 悪性腫瘍 & 計 \\
\hline$\sim 19$ & 1 & 0 & 1 \\
$20 \sim 29$ & 3 & 0 & 3 \\
$30 \sim 39$ & 2 & 1 & 3 \\
$40 \sim 49$ & 5 & 3 & 8 \\
$50 \sim 59$ & 7 & 3 & 10 \\
$60 \sim 69$ & 4 & 10 & 14 \\
$70 \sim 79$ & 1 & 1 & 2
\end{tabular}

表 5 口蓋腫瘍の発生部位別分布

\begin{tabular}{c|r|r|r|r|r|r}
\hline \hline \multirow{2}{*}{ 部 位 } & \multicolumn{2}{|c|}{ 良性腫痬 } & \multicolumn{2}{|c|}{ 悪性腫瘍 } & \multicolumn{2}{|c}{ 計 } \\
\cline { 2 - 7 } & 例数 & $\%$ & 例数 & $\%$ & 例数 & $\%$ \\
\hline 軟口蓋 & 6 & 26.1 & 6 & 33.3 & 12 & 29.3 \\
硬口蓋 & 16 & 69.6 & 11 & 61.1 & 28 & 68.3 \\
両口蓋 & 1 & 4.3 & 1 & 5.6 & 2 & 2.4
\end{tabular}

表 6 口蓋腫瘍の初発症状

\begin{tabular}{c|r|r|r|r|r|r}
\hline \multirow{2}{*}{ 初発症状 } & \multicolumn{2}{|c|}{ 良性 } & \multicolumn{2}{|c|}{ 悪性腫瘍 } & \multicolumn{2}{|c}{ 計 } \\
\cline { 2 - 6 } & 例数 & $\%$ & 例数 & $\%$ & 例数 & $\%$ \\
\hline 口蓋腫瘤 & 20 & 87.0 & 14 & 77.8 & 34 & 82.9 \\
口 蓋 痛 & 1 & 4.3 & 2 & 11.1 & 3 & 7.3 \\
口腔不快感 & 2 & 8.6 & 1 & 5.6 & 3 & 7.3 \\
頸部腫瘤 & 0 & 0 & 1 & 5.6 & 1 & 2.4
\end{tabular}

\%）が 6 ケ月以内に受診し，治療をらけている が，良性腫場では 6 例 (26.0\%) にすぎなかっ た (表 7 ). しかし悪性腫韵でも 2 年以上放置し ていた症例が 4 例（23.5\%）存在していた.

6 . 病理組織型別分布

良性腫㿉23例中多形性腺腫17例 (73.9\%), 乳

表 7 症状出現から治療までの期間

\begin{tabular}{|c|c|c|c|c|}
\hline \multirow{2}{*}{ 期 間 } & \multicolumn{2}{|c|}{ 良性腫瘍 } & \multicolumn{2}{|c|}{ 悪性腫瘍 } \\
\hline & 例数 & $\%$ & 例数 & $\%$ \\
\hline$\sim 1$ ケ月 & 3 & 13.0 & 4 & 22.2 \\
\hline$\sim 6$ ケ月 & 3 & 13.0 & 8 & 44.4 \\
\hline ～ 1 年 & 3 & 13.0 & 0 & 0 \\
\hline ～ 3 年 & 4 & 17.4 & 1 & 5.6 \\
\hline ～ 5 年 & 4 & 17.4 & 4 & 22.2 \\
\hline 5 年〜 & 6 & 26.1 & 0 & 0 \\
\hline
\end{tabular}

表 8 良性口蓋腫瘍の病理組織型別分布

\begin{tabular}{l|r|r|rr|rrr}
\hline & 例数 & \multicolumn{1}{|c|}{$\%$} & 男 & \multicolumn{1}{|c|}{ 女 } & 慗口 & 硬口 & 両口 \\
\hline 蓋 & 蓋 \\
\hline 形性腺腫 & 17 & 73.9 & 5 & 12 & 5 & 11 & 1 \\
頭 腫 & 2 & 8.7 & 1 & 1 & 1 & 1 & 0 \\
学 腫 & 3 & 13.0 & 1 & 2 & 0 & 3 & 0 \\
血 管 腫 & 1 & 4.3 & 0 & 1 & 0 & 1 & 0
\end{tabular}

表 9 悪性口蓋腫瘍の病理組織型別分布

\begin{tabular}{|c|c|c|c|c|c|c|c|}
\hline & 例数 & $\%$ & 男 & 女 & $\begin{array}{l}\text { 軟口 } \\
\text { 蓋 }\end{array}$ & $\begin{array}{l}\text { 硬口 } \\
\text { 蓋 }\end{array}$ & $\begin{array}{l}\text { 両口 } \\
\text { 蓋 } \\
\end{array}$ \\
\hline 扁平上皮癌 & 10 & 55.5 & 7 & 3 & 3 & 6 & 1 \\
\hline $\begin{array}{l}\text { 腺様のう胞 } \\
\text { 癌 }\end{array}$ & 5 & 27.7 & 4 & 1 & 3 & 2 & 0 \\
\hline 腫 & 1 & 5.6 & 0 & 1 & 0 & 1 & 0 \\
\hline 乳頭状腺癌 & 1 & 5.6 & 1 & 0 & 0 & 1 & 0 \\
\hline $\begin{array}{l}\text { 悪性リンパ } \\
\text { 尰 }\end{array}$ & 1 & 5.6 & 0 & 1 & 0 & 1 & 0 \\
\hline
\end{tabular}

表10 悪性口蓋腫瘍の頸部リンパ節転移

\begin{tabular}{c|c|c|c}
\hline & 軟口蓋 & 硬口蓋 & 両口蓋 \\
\hline 総症例数 & 6 & 11 & 1 \\
転移症例数 & 1 & 3 & 1 \\
$\%$ & 16.7 & 27.3 & 100
\end{tabular}


頭腫 2 例 $(8.7 \%)$, 外骨腫 3 例 (13.0\%), 血管 腫 1 例（4.3\%）であった（表 8 ）. 多形性腺腫 は女，硬口蓋に好発し，このことが良性腫瘍全 体の性別，発生部位別分布に大きく影響してい ると考兄られた。

覀性腫瘍18例中扁平上皮癌10例 (55.5\%), 腺 様の 胞癌 5 例 $(27.7 \%)$, リンパ上皮腫, 乳頭 状腺癌，悪性リンパ腫それぞれ 1 例 $(5.6 \%)$ であった（表 9 ). 扁平上皮癌は男, 硬口蓋に好 発していた。 また腺様のう胞癌は男に好発して いた.

\section{7. 頸部リンパ節転移}

初診時に頸部リンパ節転移を認めたのは，扁 平上皮癌 4 例, リンパ上皮腫 1 例の計 5 例であ った，軟口蓋に発生した 6 例中 1 例，硬口蓋に 発生した11例中 3 例に頸部リンパ節転移を認め た（表10）。

\section{8. 治療法}

良性腫瘍23例中22例に外科的治療が施行され た. 腫瘍被膜の外側で周囲と剝離して摘出する 腫瘍摘出術が15例，周囲の正常組織を含めて切 除する腫瘍切除術が 7 例であった。この 7 例中 乳頭腫の 1 例が再発し凍結手術が追加された. また外骨腫の 1 例が末治療であった。

覀性腫瘍18例中手術療法之放射線療法の併用 が 5 例, 放射線療法と化学療法の併用が 4 例, 放射線, 手術, 化学療法の 3 者併用が 3 例, 化 学療法と手術療法の併用が 2 例, 放射線療法単 独が 2 例, 手術療法単独が 2 例であった。手術 療法の内容は, 広沉切除術, 単純摘出術, 頸部 リンパ節摘出術，姑息的腫瘍切除術であった。 放射線療法はコバルト外照射とラジウム針によ る組織内照射であった，化学療法は 5-FU の 点滴静注が主で, Bleomycin の局所注入が 1 例で施行されていた（表11）.

\section{9. 経過と予後}

良性腫瘍23例中 1 例に局所再発を認めた，硬 口蓋乳頭腫の症例であり凍結手術が 追加され た．悪性変化を認めた症例はなかった。術後硬 結，腫脹，潰瘍などを認めた症例は乳頭腫の再
表11 悪性口蓋腫瘍の治療内容

\begin{tabular}{|c|c|c|c|}
\hline \multicolumn{3}{|l|}{ 手術療法 } & 12例 \\
\hline \multicolumn{3}{|c|}{ 広汎切除術 } & 10例 \\
\hline \multicolumn{3}{|c|}{ 姑息的切除術 } & 1例 \\
\hline \multicolumn{3}{|c|}{ 単純摘出術 } & 1例 \\
\hline \multicolumn{3}{|l|}{ 放射線療法 } & 13例 \\
\hline \multicolumn{3}{|c|}{ ユバルト外照射 } & 12例 \\
\hline \multicolumn{3}{|c|}{ ラジウム針 } & 1例 \\
\hline \multicolumn{3}{|l|}{ 化学療法 } & 7例 \\
\hline \multicolumn{3}{|c|}{ 5-Fu 静注 } & 6例 \\
\hline \multicolumn{3}{|c|}{ ブレオマイシン局注 } & 1例 \\
\hline \multicolumn{4}{|c|}{ 表12 組織型別の粗生存率 } \\
\hline 組 織 型 & 1 年 & 3 年 & 5 年 \\
\hline 扁平上皮癌 & $90 \%$ & $80 \%$ & $70 \%$ \\
\hline 腺様のう胞癌 & $100 \%$ & $100 \%$ & $100 \%$ \\
\hline 乳頭状腺癌 & $100 \%$ & $100 \%$ & $100 \%$ \\
\hline リンパ上皮腫 & $0 \%$ & & \\
\hline 悪性リンパ腫 & $100 \%$ & $100 \%$ & $100 \%$ \\
\hline \multicolumn{4}{|c|}{ 治療法別の粗生存率 } \\
\hline 主なる治療法 & 1 年 & 3 年 & 5 年 \\
\hline 手術療法(12例) & $91.7 \%$ & $83.3 \%$ & $66.7 \%$ \\
\hline 放射線療法 ( 6 例) & $83.3 \%$ & $83.3 \%$ & $83.3 \%$ \\
\hline
\end{tabular}

発症例以外にはなかった。

悪性腫瘍18例中11例は初回治療により制御で きた。制御不能であった 7 例は初診時に頸部リ ンパ節転移を認めた 6 例と治療期間中に肺転移 をきたした 1 例であった。悪性腫瘍全体の粗生 存率は 1 年で $88.9 \%, 3$ 年で $83.3 \%, 5$ 年で72 .2\%であった．悪性腫瘍の組織型別に予後をみ ると，扁平上皮癌とその類縁疾患であるリンパ 上皮腫の予後が不良であった（表12）。これは 組織型による予後の差が大きいことを示してい る。 また治療法を主体となる方法で手術療法を 放射線療法に大別して予後への影響をみた。手 術療法より放射線療法の方が高い 5 年粗生存率 を得ていた（表13）. 


\section{考}

1．良性口蓋腫瘍について

良性腫瘍が口蓋腫痬全体に占める割合はわれ われの集計では $56.1 \%$ であり，良性腫瘍が悪性 腫瘍より多い結果であった。この結果は佐々 木らの報告に近いものであったが，佐藤ら ${ }^{4)}$ ，

Beiswanger $^{2)}$ の報告をみると，悪性腫瘍が多 く良性腫瘍と悪性腫瘍の比は約 $1 ： 1.5$ であっ た。

良性腫瘍の 中では多形性 腺腫が 17例（73.9 \%)を占めていた。多形性腺腫の口腔内では口 蓋に最も好発し, その発生頻度は小唾液腺の分

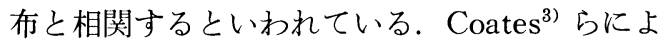
ると口蓋の小唾液腺は硬口蓋に約 250 個, 軟口 蓋に約 100 個，口蓋垂には12個存在する．口腔 内の小睡液腺数は Ranger $5^{8)}$ によると約 450 であり，口蓋とくに硬口蓋に小唾液腺は大きく 分布していることがわかる，われわれの集計で は多形性腺腫17例中硬口蓋に11例, 軟口蓋に 5 例, 両口蓋にわたるものが 1 例であり, 多形性 腺腫の発生と小唾液腺の分布が相関していた. また多形性腺腫は良性腫瘍と分類されるが，腫 瘍の悪性化や切除術後の再発といら問題をもっ ている. Ahlbom ${ }^{1)}$ が述べているよらに被膜を 破って被膜の外に腫瘍塊がみられるものや，多 少の細胞異型性を示す semi-malignant なもの が多形性腺腫の中に存在するからである，藤林 ら")の集計では多形性腺腫96例中13例に semimalignant な組織所見を認めている。したがっ て多形性腺腫の治療は摘出術よりも正常組織を 含めた切除術を選択すべきである，われわれの 集計では17例の多形性腺腫中16例に摘出術が施 行されていたが，再発や悪性化を認めた症例は なかった。

乳頭腫は口蓋腫瘍の中で低頻度のものであ る.われわれの集計では口蓋腫瘍 23例中 2 例 (8.7\%), 佐藤らの報告でも 156 例中11例 (7.1 \%)であった。これに対し欧米の報告をみると Kohn ら ${ }^{5)}$, New ら の約 $50 \%$ を乳頭腫が占めていた。本邦と欧米と
察

の乳頭腫の発生頻度の差が明らかである.

乳頭腫, 多形性腺腫の他に口蓋にはのう腺 腫, 膨大細胞腫などの上皮性腫瘍と線維腫, 血 管腫などの非上皮性腫瘍が発生する。これらの 頻度は少なく，われわれの集計では血管腫と外 骨腫を認めた。

2. 悪性口蓋腫瘍について

口蓋は舌についで口腔内悪性腫瘍の第 2 の好 発部位である. Beiswanger ${ }^{2)}$ によると悪性口 蓋腫瘍は口腔内腫瘍の約 $12.5 \%$ 占めている.

悪性口蓋腫瘍の中で最多のものは扁平上皮癌 である.われわれの集計でも扁平上皮癌が悪性 口蓋腫瘍の $55.5 \%$ 占め, 佐藤ら ${ }^{10)}, \mathrm{New} ら^{7)}$ の報告に近似していた。 また扁平上皮癌は軟口 蓋に好発するといわれるが，われわれの集計で は硬口蓋に多発していた。治療法は手術療法と 放射線療法が主体であり，化学療法は補助的な ものであった．扁平上皮癌の予後はわれわれの 集計で 5 年生存率 $70 \%$ と佐藤らの報告よりかな り高率であった，予後に影響するのは頸部りン パ節転移の有無であり，頸部リンパ節転移を認 めた 4 症例はすべて 5 年以内に死亡していた。

悪性の唾液腺腫瘍は口腔内では口蓋に最も好 発する. 腺様のう胞癌, 腺房細胞癌, 覀性多形 性腺腫などがみられ, 中でも腺様のら胞癌の頻 度は高い. 腺様のう胞癌は臨床経過が緩慢であ るが，組織学的に浸潤性増殖が強く肺，所属リ ンパ節転移が多い特徴をもっている。われわれ の集計結果もこの特徵を支持するものであっ た. また腺様のら胞癌は術後 12 年経過して肺転 移が発生した症例が藤林ら ${ }^{4)}$ の報告にあり, 長 期間の経過観察が必要である，われわれの集計 では 5 年以内に死亡した腺様のら胞癌症例はな かったが，15年間にわたって入院加療を反復す る症例もあり初回治療の重要性を痛感させた。

以上のように悪性口蓋腫瘍は組織型によって 治療法と予後は様々であるが, 臨床像による腫 瘍の鑑別が困難な場合もあり十分な注意が必要 である。 
鳥取大学医学部耳鼻咽喉科選室で過去35年間に経験した口蓋腫焬41例を集計し, 性, 年令, 発生 部位, 初発症状, 症状発生から治療までの期間, 病理組織型, 頸部リンパ節転移, 治療法そして子 後の 9 点について検討した，41例中良性腫瘍23例，悪性腫瘍18例であった．良性腫瘍23例中17例が 多形性腺腫であり，この腫瘍の予後は良好で再発，悪性変化はなかった．悪性腫瘍18例中扁平上皮 癌10例, 腺様のら胞癌 5 例であり, リンパ上皮腫, 悪性リンパ腫, 乳頭状腺癌がそれぞれ 1 例であ った。扁平上皮癌より腺様のら胞癌の方が経過が長く生存率が高かった。 また口蓋腫瘍全体の 56.1 \%を小唾液腺腫瘍が占めていた。

悪性口蓋腫瘍の予後は, 組織型と頸部リンパ節転移の有無に大きく影響される結果を得た.

本論文の要旨の一部は第 8 回日耳鼻咽喉科学中国・四国地方部会連合会で発表した.

御校閲いただいた恩師生駒尚秋教授に深謝いたします。

\section{文献}

1) Ahlbom HE: Mucous-and salivary gland tumours. Clinical study with special reference to radiotherapy, based on 254 cases treated at the Radiumhemmet. Acta Radiol [Suppl] (Stockh) $23: 1 \sim 13,1935$.

2) Beiswanger RH : Carcinoma of the cheek, alveolar process, Floor of mouth, and Palate. Radiology 44 : 213 224, 1945.

3 ) Coates HL, et al: Glandular Tumors of the palate. Surg Gynecol obstet 140: 589 593, 1975.

4 ) 藤林孝司, 他: 小唾液腺腫瘍の臨床的研究. 日本 口腔科会誌 $21: 901 \sim 928,1972$.

5 ) Kohn EM, et al: Primary neoplasms of the hard and soft palates and the uvula. Proceedings of the staff meeting of the Mayo clinic, 38 : 233 239, 1963.

6) Martin H: Tumor of the palate (benign and malignant). Arch Surg 44: 599 635, 1942.

7 ) New GB, et al: The End-results of the treatment of malignant tumors of the palate. Surg Gynecol Obstet 73: 520 524, 1941.

8 ) Ranger $\mathrm{D}$, et al: Mucous gland tumours. $\mathrm{Br}$ J Cancer $10: 1 \sim 7,1970$.

9 ) 佐々木治夫, 他：口蓋腫瘍について。耳喉 42: 959 965, 1970.

10）佐藤文彦, 他: 口蓋悪性腫瘍の臨床的観察一過去 13年間の集計から一. 耳鼻臨床 $67:$ 159 166, 1974.

11) Seiferth LB, et al: 唾液腺腫瘍の病理と臨休: 耳鼻臨床５9：627〜637, 1966.

$\left(\begin{array}{l}\text { 別刷請求先 : 中島幹夫 } \\ \text { T683 米子市西町 } 86 \\ \text { 鳥取大学医学部耳鼻咽喉科学教室 }\end{array}\right)$ 